\title{
Existential Maturity of Savitri in the Dark Room by R. K. Narayan
}

\author{
Ramesh Prasad Adhikary \\ http://dx.doi./org/10.4314/ujah.v21i1.6
}

\section{Abstract}

This article is mainly focused on the protagonist Savitri of the novel: The Dark Room by R.K. Narayan and how she is alienated from herself, from society and from the world and about her quest for marital identity. Savitri also goes through the crisis of discontent to the quest for happiness. Savitri of the ancient legend is a paragon of virtue and courage who confronts even Death to save her husband is finally victorious. Ironically, unlike the legendary Savitri, Narayan's Savitri chooses to leave home, husband and children once she comes to know of her husband's infidelity. Contrary to the legend, Savitri is just an ordinary, amiable, housewife. She abandons her gambler and drunkard husband and her family. But her independence proves detrimental to Savitri's familial peace. Narayan skillfully portrays her every action and in his ironic subtle fashion puts across the artificiality behind it.

Keywords: Existence, anxiety, alienation, existential struggle, choice of freedom, frustration 


\section{Introduction}

Indo-Anglican literature, which forms almost an integral part of English literature, has now attained a distinct place in the literary landscape of India. Indian writing in English fiction has been acclaimed around the world for its innovative and radical new approaches to storytelling. The multitude of such writing explores India in its various aspects. Apart from the continued literary output by the older generation of Indian English writers, we also have newer generation that explores the contemporary angst, alienation and existentialism felt by the 'middle class liberal humanist'.

R. K. Narayan was born on 10 October, 1906, in Madras. He began his writing career with Swami and Friends in 1935. Most of his works including Swami and Friends is set in the fictional town of Malgudi, which captures everything Indian while having a unique identity of its own. His writing style was marked by simplicity and subtle humour. He told stories of ordinary people trying to live their simple lives in a changing world.

The Dark Room (1938) presents the struggle of a sensitive woman, Savitri struggling to come into terms with her predicament as the wife of an adulterous husband after having married for fifteen years. Savitri has received nothing from her husband Ramani except rebukes and abuses. He treats the children similarly. She then revolts and leaves the house in despair to commit suicide. She is saved, decides to live an independent life but realizes the futility of her attempt to escape from her bonds with the temporal world and returns home.

This study is about the existential maturity shown by R.K. Narayan's characters at the time of crisis on his famous fiction The Dark Room. The aim is to focus on how she overcomes them and 
how she decided to lead a fulfilling life. It also explores the psyche depth of his characters.

\section{Existentialism and Freedom of Choice}

Existentialism analyzes the existence of human beings and impels light on the way they find themselves existing in the world. Soren Kierkegaard, the 19th century philosopher is regarded as The Father of existentialism. He maintained that the individual has the sole responsibility for giving one's own life meaning and with living life passionately and sincerely despite many obstacles and distractions including despair, angst, absurdity, choice, boredom and death.

Due to the Great Depression of 1930 and World War II, people all over the world were affected and a deep sense of despair prevailed in the society. It was then the existentialistic ideas came out in society. The spirit of optimism in the society was totally destroyed by World War I and its mid-century calamities. This despair has been articulated well not only in the $20^{\text {th }}$ century but also in the 21 st century.

Existentialism is a philosophy of reaffirming and regaining the lost status of man in the advanced scientific and technological society. In this modern society, the creator of science himself becomes a victim of his own creation and feels like a mere $\operatorname{cog}$ in a highly mechanized system. Various existentialists differ on the fundamental problems but agree on perceiving certain objective realities like the crisis in human values, the significance of human anxiety, deprivation of human freedom and importance of human emotions. No emotional problem is more threatening than the existential problem.

Søren Kierkegaard, claimed "life for the individual is a risk-filled existence", (7) and it is on this basis that Existentialism 
is founded. David Cooper in his book 'Existentialism'; elaborately explains that this philosophy offers a positive way through the themes of anxiety, alienation, uncertainty, possibilities and crisis. Therefore, there is a growing interest in Existentialism recently."Feelings of anxiety or angst can be manifested when one gets alienated." (8) The individuals are uncertain as to how the new world is going to emerge as these themes dismantle one's world and leaves it in an unfinished state. A central focus is upon the individual rather than on the masses. Existential writings are aimed to engage each reader as an entity. Kierkegaard often referred to 'my dear reader' and the 'existing individual' and Nietzsche often used phrases such as 'the sovereign individual' and 'the superman'. (9) Heidegger referred to Dasein, meaning literally 'being there' - to represent where the individual is at, with regards to her or his concerns for existence in relation to being. (10)

One must note that no doctrine is more optimistic than existentialism. The destiny of man is placed within himself. Initially existentialism did appear to be a morbid philosophy because it deals with depressing themes such as alienation, anxiety, death and crisis. However, the purposes of so many of the philosophers who have contributed to this school of thought have had a vision that is to allow people to experience a greater richness and happiness in their lives and to feel at 'home' in their world. In order to achieve a richer and more valuable existence however, the philosophy often refers to some 'uncomfortable' suggestions. For example, the individual is encouraged to stand at the edge of the abyss, to introspect oneself and to contemplate the terror of freedom and then to make a leap. At the point of departure there cannot be any other truth than this, "I think, therefore, I exist." (11) which is the absolute truth of consciousness. 
The inevitabilities of human condition may give a bleak picture but existentialism has optimism and hope because of the potential the human condition has and all people have to transcend those inevitabilities. An inherent aspect of this concept of freedom of choice is responsibility. The existential perspective developed here considers that the individual who exercises personal freedom of choice must also be willing to accept responsibility for these decisions. But, the individuals find it difficult to accept that they always have possibilities and are free to choose between them. They may not have the choice to affect the 'objective reality' of certain entities, but they do have possibilities in how they relate to their relations with other entities. This means that individuals are responsible for their subjective/inward existence, which can be a daunting challenge.

Existential psychology is about human existence and the human drama of survival. It helps in overcoming or confronting existential anxieties and living an authentic life. Existentialist psychologists avoid treating a person as if they were isolated from events and situations in the world. The features of choice, responsibility, and freedom in human lives are of particular importance in existential psychology. For both good and bad, people are expected to seize their freedom and take responsibility for the choices they make in their lives.

Choice is one of the most fundamental concerns in existentialism. We may not choose to be born but, once born, we are responsible for the lives we lead. We create the structure of the world around us and realize our self based on our choices and decisions, even though there are factors that aren't entirely within our control.

The concept of Self-realization or inner self has become widely popular in the Western world, greatly influenced by some 
Eastern religions. In the Hindu religion, self-realization refers to profound spiritual awakening. The branch of Advaita Vedanta is the one that has especially developed this concept.

\section{Existential Maturity Shown by Savitri}

The Dark Room presents marital unhappiness and domestic disharmony. Narayan sets down a fragment of life as he actually sees. Though the storyline is thin, underlying theme is profoundly realistic and presents the struggle of a sensitive woman to come to terms with her predicament. The crisis in the novel is adultery. The heroine is left trapped in an existential predicament of unrequited moral struggle close to life in death: "A part of me is dead."(DR. p. 92)

The Dark Room and Savitri are deliberately named so by Narayan. The Dark room for the dark room in the house is a room used to store junk of the house. The protagonist Savitri identifies herself with the junk, which has outlived its utility. The room is dark and she feels that there is no light waiting at the end of the tunnel. Her self- worth is wounded. According to Harrex, the dark room here symbolizes as: "the emotional and domestic claustrophia which can result from a circumscribed marital orthodoxy."

The Dark Room portrays the protagonist alienated from herself, from the society and from the world and is in quest for marital identity. Savitri also goes through the crisis of discontent to the quest for happiness.

Savitri of the ancient legend is a paragon of virtue and courage who confronts even Death to save her husband is finally victorious. Ironically unlike the legendary Savitri, Narayan's Savitri chooses to leave home, husband and children once she comes to know of her husband's infidelity. There is a touch of 
irony at the start of the novel when her husband tells Savitri: "What a dutiful wife! Would rather starve than precede her husband. You are some of the women in our ancient books." (DR p.11). Contrary to the legend, Savitri is just an ordinary, amiable, housewife. Our first impression is that of a traditional, docile and submissive Indian wife.

The wives, mothers, grandmothers all illustrate the passive feminine characters in Narayan's novels. They are not even named. They are merely slotted. The Dark Room is the only novel of Narayan which is woman- centric until A Grandmother's tale (1993), his last book which was a novella. After the first two novels ending with a positive note, the narrative technique with a dramatic element is incorporated with themes of dissonance and despair in marital relationship between the protagonist Ramani and Savitri. The heroine of the novel is Savitri. There are two critical phases in the novel. The second phase has greater intensity as it throws light on the disintegration of the family whose familial ties were amiable in the first phase.

In the first phase, Ramani showers all the love and affection and takes Savitr into the cinema. He sits in the first class seat with his wife by his side. He is proud of her and has satisfaction of possessing her. He decides to take her separately and take the children the next day. He is very possessive and constantly enquires if her chair is comfortable. "It's a Tamil film. I thought you would like it" (DR. p. 22). He also wants her to see the film care free without bothering about children.

When Ramani claims the children as his own, she breaks down: "Yes, you are right. They are yours, absolutely. You paid the midwife and the nurse. You pay for their clothes and teachers. You are right. Didn't I say a woman owns nothing?"(DR. p. 88). 
She is totally heartbroken and in Harish Raizada's words: "She feels that she has been denied the dignity of living a human being and has to depend on her father, husband and children." (DR p. 26). Realization of her helplessness hits Savitri: "I don't possess anything in this world. What possession can a woman call her own except her body? Everything else that she has is her father's, her husband's or her son's." (DR, p. 43). Ramani's words pierce her heart when he says: "They will get on splendidly without you, don't worry. No one is indispensable in this world!!" $(D R)$

Ramani has been very domineering and cynical in his ways and is very authoritative. He is also very strict with his children. $\mathrm{He}$ has complete control over his family and this behaviour is enough for Savitri to go through the mental agony. Now, to add to it he also has an affair with his office secretary, Shantabai, a new employee in his office who has deserted her husband and has joined as an insurance canvasser. Savitri confronts him and forewarns him of the consequences.

Realizing that all her life she has been treated as a stooge first by her father before marriage and secondly by her husband, she grows into a rebel against the traditionally defined position of women in Indian society. A meek Savitri turns against the mythical implications of her name, protesting that she is a human being and that in general men never agree to it. For them women are playthings. When they feel like hugging, they hug otherwise are slaves to them. She also retorts that men should not think that they can fondle women whenever they wish and kick them whenever they choose. "He does not bother and refuses to change his ways. She rebels and shouts at him saying that he should not touch her, $\mathrm{He}$ is impure and even if she burns her skin, she will not be able to cleanse herself of impurity of his touch" (DR. p.87). 
The scene vividly depicts the agonized and tormented wife's rage and sentiments. Savitri is shattered with the repeated reprimands, rebuke, and now infidelity from her husband of fifteen year leaves the house to commit suicide. She decides to go emptyhanded leaving all her ornaments. She also leaves behind the ornaments given by her father too because she feels that all men are alike and doesn't want to depend upon any men. Her existential agony is unbearable and she rightly retorts: "What is the difference between a prostitute and married women? - the prostitute changes her men, but a married woman doesn't; that is all, both earn their food and shelter in the same manner" (DR. p. 97).

Her interior monologue reveals her mental anguish and she feels pity for the women who have no support. Savitri is on her way to commit suicide in the Sarayu River. Narayan reveals her state of mind where she herself is amazed at her rebellion. "She feels that she has changed. She imagines whether she is the old Savitri or someone else. This must be a dream and she does not have the courage to talk back to her husband and she has never done it in her life"(DR 115,116). She can never think of indulging in any controversies with her husband. Thus, after her decision of leaving home, she is caught in a conflict between a wifely devotion and her new individual existence.

It is my dispute that Narayan is being accurate in portraying his women as inclined by traditions and customs and other values sustained by society. We can see that women even today believe in conforming to pacts at least most of them do. By presenting both the kinds of women the conventional and non-conformist side by side in this novel, R. K. Narayan is being true to life. It would seem too artificial and contrived if we had only one ideal type of woman because this is not the case in society. 
Shantabai has questioned the traditions and conventions of society. She defies them in leaving her husband and ending her marriage. The need to be free from bonds of matrimony and commitment is great but in her attempt to be free, she drifts anchorless for want of an ideal alternative to traditional values. In modern woman's quest for self-fulfillment, apart from facing personal and social conflicts, she also has to undergo the painful experience of severing the family bonds and re-establishing herself. Shantabai is the proverbial butterfly, the type of woman who imitates her western counterpart. She is an educative, manipulative seductress who knows how to use woman's charm to win the man. She is cunning and makes the right move to trap her prey. He visits her home for the first time; her style of talking is conspicuous of her intention of enticing him. She narrated her sob story and at the end of every ten minutes of her narration she would say: "As for me life is ... something or other, some simple affair like Living Today and Letting Tomorrow Take Care of Itself or Honour being the One Important Possession and so forth." (DR, p.63)

She defies the traditional status of the woman in Indian society. She abandons her gambler and drunkard husband and her family. But her independence proves detrimental to Savitri's familial peace. In Shantabai we find all the characteristics of a 'coquette' in Indo English literature. Narayan skillfully portrays her every action and in his ironic subtle fashion puts across the artificiality behind it. She shows how she compresses her lips, tosses her head in perfect Garbo manner: the temperamental heroine and the impending doom.

Narayan shows how she poses as an intellectual and explains her own philosophy of life: "Tonight, I feel like pacing the whole earth up and down. I won't sleep. I won't sleep. I feel 
like roaming all over the town and the whole length of the river. I will laugh and dance. That's the philosophy of my life." (DR p. 68)

R.K.Narayan has created Shantabai not just to reveal or portray the other type of woman but also to point out indirectly the hypocrisy implicit in middle class value systems. Shantabai represents the pseudo-emancipated woman who in her outward manner seems to know exactly what she wants and how she gets it. Ramani is hopelessly spellbound by her. Her theatrical display of hysterics moves him deeply and he contrasts it with his wife's crude sulking in the dark room. Shantabai indirectly brings certain hypocrisies of the male psyche to the fore.

Narayan gives the women a chance to break away from the fold and assert their strength. But then again it cannot be said that making them return is a contrived act. When the women break away from the fold as Savitri does or when they undergo suffering they become aware of their inner selves and of the predicament of women in general. The experience of self-realization is a transforming experience. Her existential crisis is vividly portrayed in the following lines: "One definite thing in life is fear. Fear from the cradle to the funeral pyre and even beyond that, fear of torture in the other world. She is also afraid of her husband's displeasures and of the discomforts" (DR. p. 69).

Gangu is an educated woman and Savitri's friend, who stays in the neighbourhood. She aspires to be a professional singer. Her husband is a teacher. She is a Malgudi delegate to the All India Women's Conference and a politician. She has full support of her husband who believes in women's freedom. Her husband is very broadminded and she manages to keep a balance between tradition and independence. She too has her daily squabbles and has thrown everything at home. She comes to meet Savitri and confesses her mood swings that day. She tells her husband: "Don't expect any 
tiffin this evening when you come back from school. I would advise you to fill your stomach in a hotel." (DR. p. 76.)

She tells Savitri that he has to get a packet for her and the children otherwise he will be driven back out to get them. Gangu is the new woman, whom Narayan throws light on being at par with her man. Gangu is the one to convey to Savitri about her husband's scandalous affair. She had seen Shantabai with Ramani in the theatre watching the film. She indirectly instigates her to assert herself, question her husband about the affair.

Narayan throws light on the woman Ponni of the Sukkur village whose husband Mari saves Savitri when she attempts to commit suicide. Mari was a burglar at night and a blacksmith during the day. He cared for his wife although he chased her about and threw things at her whenever he was drunk. Ponni has been a dominating woman and Mari does fear her. Ponni is a childless middle aged woman, who is vulnerable but is a woman who has complete freedom and dominance over her husband, Mari.

After listening to Savitri's predicament, Ponni advises the vanquished Savitri how to manage and treat a man. She says: "Sister, remember this. Keep the men under the rod and they will be all right. Show them that you care for them and they will tie you up and treat you like a dog" (DR. p.105).

Perhaps what Narayan wants to emphasize in his indirect subtle way is that self-realization is the first step towards selfactualization. In fact, to emphasize that all women characters in his novels conform to conventions and traditions, does not mean that they are passive and meek. They are inherently passive because they are conditioned to be passive and in embracing the traditional values and upholding them they prove not only wiser but also stronger. The women emerge after the turmoil stronger in spirit and go about their lives with greater knowledge and strength. 
While Narayan makes them come back and accept the dictate of the society, the women are no longer the same, docile weak persons that they were at the start.

His novels reflect on his narration. He is detached observer and leaves the interpretation to the reader. In India men make fun of a woman if she speaks of freedom. Men may appear to think that when woman becomes aware of her capabilities, she stops being a woman! Herein lies their faulty thinking.

The word 'freedom' is misconceived, misunderstood. Freedom from whom? Freedom from what? In fact, the Indian woman has chained to her own misconceived ideas, there are number of shackles around her. But the fact is today these shackles are rusted but she is not aware of the rust. She has to awaken from her slumber. She has to see the things in their true perspective and colours. She has to recognize her own SELF. That can happen only when she discards her fear out of her mind. But in reality is it easy for an Indian woman to cast fear of society and its dictates, to lead independent individual life?

Freedom is certainly the concept when one is reminded about the women's lib. R. K. Narayan has admitted being obsessed with the philosophy of woman as opposed to man, her constant oppressor. This must have been an early testament of the Women's Liberation movement. The following lines in the book are a standing testimony to his farsightedness and existential vision:

I was somehow obsessed with a philosophy of woman as opposed to man, her constant oppressor. This must have been an early testament of the 'Women's Lib' movement. Man assigned her secondary place and kept her there with such subtlety and cunning that she herself began to lose all notion of her independence, individuality, stature and strength. A wife in an orthodox milieu of the Indian society 
was an ideal victim of such circumstances. My novel dealt with her, with this philosophy broadly in the background. (26)

R. K. Narayan being a traditionalist lauds the resilience of women who face all kinds of pressures from different quarters and yet emerges quietly triumphant and all wiser for it. Psychological deliberations underline acute awareness of general human concerns that transcend the novels' rootedness in India. R. K. Narayan has employed the streams of consciousness technique in the context of Indian consciousness and not the consciousness of Camus or Kafka's protagonist. He documents the critical moments of the protagonist's life when she is faced with a psychic crisis in to selfrevealing internal monologues:

A dutiful wife, she has not to be obedient and loyal: "There is no quarrel. I have not uttered (use the) word".... That makes it worse. You should either let your words out or feel that everything your husband or argued with him at any time in my life. I might have occasionally suggested an alternative but nothing more, what he does is right. It is a wife's duty to feel so (DR. p. 42).

Bullying husbands like Ramani and patient wives like Savitri was the scene in numerous household of those times. It is still prevailing in a male dominated society of the 21 st century and is the hapless plight of many Indian housewives.

P. S. Sundaram maintains: "The bully who will bring guests into the house without notice and expect them to be fed is hardly thought of as a bully by anyone. It is the India tradition to honour the guest as God, to share whatever one has with the stranger." (28). The stream of beliefs of Savitri is not incessant. The impartial declaration soften intercept them. Interior monologue and 
soliloquy is a sensitive representation of Savitri's oppressed female psyche. He executes the stream of consciousness technique to project the psychic reverberations of her character in order to lend authenticity to the narration.

The Hindu mind still prevails. The Hindu philosophy, the classical theory of Karma implies a pragmatic approach to life's problems. It is held that an effective experience is painful or pleasurable because karmic traces are produced by our actions and so deserved. Every man has to live out his own Karma. The reality of the writers' predicament is the reality of a universal predicament. The quest for an individual identity in psychological realism is being authentic to one's evolving self.

Thus, R. K. Narayan cannot be tallied as a feminist and he never claims to be one but he really considers women's issues consciously from the very beginning. The women in R. K. Narayan's work are reflective of the women he saw in life around him. He does promote the status of women but does not show that westernization to be the only way out. The fiction of Narayan can be regarded as epics capturing modern India's plight. His fictional town, Malgudi serves as the periscope for observing the living state of women, the challenges and problems they face in reality. Hence, it is rightly stated by Simone de Beauvoir, a French author, philosopher that: "One is not born a woman, but becomes one." (29)

Narayan thus progressively creates a healthier position for women within India's own traditions. His women characters grow stronger and show the advent of New Woman who will uphold the traditional values and also be self-reliant. Savitri is fully aware of the dignity a woman possesses and she knows that by succumbing to the status quo which includes Ramani's petty tyrannies and flirtation, she has proved be her own enemy like Janamma. What 
she needs is courage recalls Virginia Woolf: "Courage in the manner of Moll Flanders, the power to stand her ground" (30)

After such unpleasant involvements, a new awareness stifles in her. She has to make a choice and lead a meaningful life. When Mari passes by her window, her natural urge is to rush out, hail him and reward him for having helped her. But she feels it's futile and is helpless: "What am I? A part of me is dead.... Why should I call him? What have I?" (DR. p. 162)

Though such questions worry her, she is not the meek and timid Savitri anymore. Her new awareness would enable her to see that her daughters at least do not fall in the same trap when they grow. Nazar Singh Sidhu asserts: "The dark room in the ultimate analysis becomes a point of irony -the more Savitri suffers behind its dark, the more she achieves her authentic self." (31)

In this milieu alienation is the very essence of existence and the most glorious recovery of being. She overcomes all the existential storms through patience and fortitude and the belongingness towards Malgudi. This simple novel brings out Narayan's concern for the 'Savitris' of our country. Savitri is an agent for Narayan's quest for psychological insight and awareness of the plight of unfortunate woman who has neither the strength of will nor the economic and educational opportunities to withstand unfair male aggression. Narayan's view matches with Dr Paul Wong's duality hypothesis. It states that positives cannot exist apart from negatives and that authentic happiness grows from pain and suffering. This hypothesis reflects Albert Camus insights: There is no joy without despair. (32)

Narayan is quite conscious of the complexity of the experience. Uma Parmeswaran, a critic states: "Though Narayan's vision is positive his 'affirmation is not a thunderous one, it is found only if one looks for it." (33). This justification cannot be 
accepted. When the claim of affirmation is doubted the question whether it is so bold or not is not significant.

\section{Conclusion}

The Dark Room portrays the protagonist alienated from herself, from society and from the world and is in quest for marital identity. Savitri also goes through the crisis of discontent to the quest for happiness. Savitri of the ancient legend is a paragon of virtue and courage who confronts even Death to save her husband is finally victorious. Ironically, unlike the legendary Savitri, Narayan's Savitri chooses to leave home, husband and children once she comes to know of her husband's infidelity. There is a touch of irony at the start of the novel when her husband tells Savitri: "What a dutiful wife! Would rather starve than precede her husband. You are some of the women in our ancient books."(DR p.11). Contrary to the legend, Savitri is just an ordinary, amiable, housewife. Our first impression is that of a traditional, docile and submissive Indian wife. She showed her existential maturity at the time of crisis.

\section{Ramesh Prasad Adhikary}

Tribhuwan University, M.M. Campus, Nepalgunj (Nepal) rameshadhikary29@gmail.com 


\section{Work Cited}

Camus, Albert. The Myth of Sisyphus and Other Essays. New York: Vintage Books, 1923.

Hudson, W.H. An Introduction to the study of literature, New Delhi: Atlantic Publishers and Distributors, 2010.

Jaspers, Karl. Man in the Modern Age trans. E and C. Paul, Kegan

Paul \& Henry Holt \& co. Revised edition, 1952

Kierkegaard, Soren. Sickness Unto Death. London: Harpur,1898.

Krishnaswamy, Shanta. The Woman In Indian Fiction 1950-1980.

New Delhi: Ashish Publishing House, 2001.

Krishnaswamy, Shantakrishnaswamy. The Woman In Indian

Fiction 1950- 1980. New Delhi: Ashish Publishing House, 2001.

Narayan, R.K. The Dark Room. Chennai: Indian Thought Publication, 1938.

Sartre, Jean-Paul. Being and Nothingness, trans. Hazel Barnes. New York: Washington Square Press. 1992.

Walsh, William. R. K. Narayan: A Critical Appreciation. New Delhi: Allied Publishers Private Ltd, 1942. 